\title{
Auger radiation targeted into DNA: a therapy perspective
}

\author{
Franz Buchegger ${ }^{1}, 2$, Florence Perillo-Adamer ${ }^{1}$, Yves M. Dupertuis ${ }^{3}$, Angelika Bischof Delaloye ${ }^{1}$ \\ ${ }^{1}$ Service of Nuclear Medicine, University Hospital of Lausanne CHUV, Rue du Bugnon 46, 1011 Lausanne, Switzerland \\ 2 Service of Nuclear Medicine, University Hospital of Lausanne, Lausanne, Switzerland \\ ${ }^{3}$ Service of Nutrition, University Hospital of Geneva, Geneva, Switzerland
}

Received: 5 April 2006 / Revised: 29 May 2006 / Accepted: 9 June 2006 / Published online: 8 August 2006

C Springer-Verlag 2006

\begin{abstract}
Background: Auger electron emitters that can be targeted into DNA of tumour cells represent an attractive systemic radiation therapy goal. In the situation of DNA-associated decay, the high linear energy transfer (LET) of Auger electrons gives a high relative biological efficacy similar to that of $\alpha$ particles. In contrast to $\alpha$ radiation, however, Auger radiation is of low toxicity when decaying outside the cell nucleus, as in cytoplasm or outside cells during blood transport. The challenge for such therapies is the requirement to target a high percentage of all cancer cells. An overview of Auger radiation therapy approaches of the past decade shows several research directions and various targeting vehicles. The latter include hormones, peptides, halogenated nucleotides, oligonucleotides and internalising antibodies.

Discussion: Here, we will discuss the basic principles of Auger electron therapy as compared with vector-guided $\alpha$ and $\beta$ radiation. We also review some radioprotection issues and briefly present the main advantages and disadvantages of the different targeting modalities that are under investigation.
\end{abstract}

Keywords: Auger radiation - Nuclear targeting Treatment - Dosimetry

Eur J Nucl Med Mol Imaging (2006) 33:1352-1363 DOI 10.1007/s00259-006-0187-2

\section{Introduction}

Current clinically useful systemic radiation therapies are mainly based on $\beta^{-}$radiation emitters [1]. Radioisotopes

Franz Buchegger (

Service of Nuclear Medicine,

University Hospital of Lausanne,

Lausanne, Switzerland

e-mail: Franz.Buchegger@chuv.ch

Tel.: +41-21-3144373; Fax: +41-21-3144349 such as ${ }^{131} \mathrm{I},{ }^{32} \mathrm{P}$ and ${ }^{89} \mathrm{Sr}$ are efficient therapeutic agents because they are taken up by cancerous or hyperactive tissues [2-8]. These $\beta^{-}$emitters and others such as ${ }^{90} \mathrm{Y}$ and ${ }^{177} \mathrm{Lu}$ have been coupled to antibodies [9-12] or peptides $[13,14]$ in order to target them into tumours for systemic radiation therapy. In recent years, $\alpha$ emitters have regained popularity with the emergence of new production processes and the availability of clinically useful targeting agents such as humanised, tumour-selective monoclonal antibodies. However, studies with $\alpha$ emitters remain mostly pre-clinical $[15,16]$. Similarly, Auger radiation therapy, while being a long-standing research goal, has encountered multiple obstacles, and clinical studies have been very scarce.

Among the different requirements of systemic radiation therapy that we shall discuss below, we first mention the importance of suitable tumour-selective vehicles. Antibodies in lymphoma therapy and peptides that bind to somatostatin receptors are the most advanced options in this respect.

A second requirement, in our opinion, aimed at increasing the efficacy of systemic radiation therapy, is the repeated application of internal emitters. Even though radiolabelled antibodies, as an example, circulate and irradiate tumours over a period of a few days, repetition of therapy might still be favourable. Repetition of therapy cycles is already in use in radio-peptide treatment. Repetition of treatment or, alternatively, continued infusion appears essential with certain radio-nucleotides that can only be incorporated in the $\mathrm{S}$ phase of the cell cycle, such as iododeoxyuridine. The aim of repeating radiotherapy cycles is the successive destruction of the most accessible and radiosensitive parts of cancer nodules. The sequential radiotherapy cycles would hit re-oxygenated, re-nourished cycling cells in radiosensitive phases, as is the case in conventional external beam radiation therapy $[17,18]$.

A third requirement of systemic radiation therapy is the targeting of radiation to large proportions of all live cancerous cells. With respect to large solid tumour nodules, the crossfire effect of $\beta^{-}$particle emitters can be a major advantage [9-12]. The long range tissue penetration, however, might be a disadvantage when targeting small clusters of tumour cells. 
Owing to their physical properties, $\alpha$ and Auger electron emitters are better adapted for the treatment of individual cells or small clusters. These two radiations provide a high linear energy transfer (high LET) type of energy deposition: $\alpha$ particles with about $80-100 \mathrm{keV} / \mu \mathrm{m}$

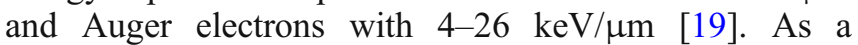
consequence, $\alpha$ radiation has a path length in tissue in the range of only $40-80 \mu \mathrm{m}$ while the path length of most Auger electrons is well below $1 \mu \mathrm{m}$. These radiations are therefore optimal for treatment of individual cancer cells or small cell clusters. The limited tissue penetration of only a few cell diameters and the rather short half-life of most available $\alpha$ emitters are the major reasons why this type of radiation is mainly appropriate for haematological malignancies [19].

In contrast to $\alpha$ and $\beta^{-}$radiation, treatment based on Auger electron emitters requires targeting of the radioisotope into individual tumour cells and even into the nucleus. Optimal Auger radiation efficacy is obtained when Auger emitters are tightly bound to DNA. Despite the multiple obstacles that have been encountered, Auger radiation therapy approaches remain appealing because of the selective toxicity for cells that incorporate the radiopharmaceutical into the nucleus. In contrast to $\alpha$ and $\beta^{-}$radiation, Auger radiation emitters remain of low toxicity while travelling in blood or bone marrow but become highly efficient when incorporated into DNA of target cells.

The high LET type energy deposition of $\alpha$ and Auger radiation in DNA produces a high proportion of double strand breaks. The double strand destruction of several nucleotides can make DNA repair [20,21] rather inefficient and prone to error. The relative biological efficacy (RBE) of $\alpha$ and Auger radiation emitters is thus significantly higher than that of $\beta^{-}$radiation. However, this is the case for both tumour and normal tissues.

\section{Fundamental requirements of systemic radiation therapy}

The first requirement of systemic radiation therapy is the definition of suitable tumour-selective vehicles in order to avoid normal tissue toxicity. Antibodies and peptides, notably those binding to somatostatin receptors, [22], are most advanced in this respect. Furthermore, two anti-CD20 antibodies for radioimmunotherapy (RIT) of lymphoma are currently FDA approved [23, 24].

It appears from these therapies that the specificity of antibodies or peptides for tumour is not an absolute requirement. Targeting of normal B cells with anti-CD20 or anti-CD22 antibodies is generally well tolerated [11, 25], probably because these antibodies do not bind to bone marrow stem cells and other cells of the immune system, notably $\mathrm{T}$ cells. In contrast, tolerance of treatment with Campath antibody (alemtuzumab) is more compromised, since its target antigen is expressed on both normal $\mathrm{B}$ and $\mathrm{T}$ lymphocytes [26]. Campath treatment can therefore provoke depression of both antibody and cellular immunity, thereby frequently leading to severe infections.
An advantage of current RIT may be the fact that it is administered in combination with high amounts of nonlabelled antibodies. The non-conjugated antibodies can themselves provide an efficient biological treatment of cancer or lymphoma and leukaemia [26-28]. Indeed, it is well documented that unlabelled monoclonal human $\operatorname{IgG}_{1}$ antibodies provide highly efficient effector functions such as complement-dependent cytotoxicity, antibody-dependent cellular cytotoxicity or direct induction of apoptosis and cell killing. Current RIT is therefore a combination treatment that favourably combines biological therapy with radiation treatment.

Treatment repetition and/or prolonged application of internal emitters, as are used in conventional radiotherapy, might be a second requirement for efficient systemic radiation therapy. However, some currently used clinical antibodies are still of rodent origin (tositumomab, ibritumomab) [23, 24], bearing the risk of immunising patients and not allowing repeated treatment cycles. It has been shown, however, that chimerisation (rituximab) [27] and, even more so, humanisation of monoclonal antibodies (alemtuzumab or trastuzumab) [26, 28] significantly reduces the risk of a human anti-mouse IgG immune response. In peptide treatment and Auger electron therapy approaches, immune response to the targeting vehicles will generally not occur, providing the opportunity to repeat treatment cycles without particular constraints.

Targeting of a high percentage of all live cancerous cells may be a third requirement of systemic radiation therapy. It is important to realise that the tumour uptake of radiolabelled antibodies, peptides and other conjugates is frequently quite inhomogeneous. In this situation, the crossfire effect of $\beta^{-}$particle emitters can constitute a major advantage [9-12]. The longer range tissue penetration of this radiation type is due to a small energy deposition on the radiation path of only $0.2 \mathrm{keV} / \mu \mathrm{m}$. $\beta^{-}$radiation is thus providing a low LET type radiation similar to X-rays. Owing to this long-range tissue penetration of $\beta^{-}$radiation, a crossfire effect is created, reaching a major portion of tumour cells rather homogeneously even in a solid tumour and despite inhomogeneous radiopharmaceutical distribution (Fig. 1). Another advantage of $\beta^{-}$radiation therapy approaches is the availability of multiple radioisotopes emitting low-, medium- and highenergy electron radiation (Table 1). These different energies provide short- to long-range tissue penetration paths of 0.1 up to $10 \mathrm{~mm}$ [29]. Optimal tumour sizes for given $\beta^{-}$energies have been modelled [30]. Results of in vivo studies, however, have not always correlated with these predictions [31,32]. The disagreement may be partially due to insufficient knowledge of microscopic distribution of the radio-vector or insufficient coverage of radiobiological issues such as killing of clonogenic cells [31].

However, it is obvious that small tumour nodules or clusters of tumour cells will not be treated efficiently with high-energy $\beta^{-}$emitters. At a small target size, energy deposition of high-energy $\beta^{-}$radiation becomes predominant in the normal surrounding tissue and insufficient in the target tumour cells. As an example, it has been calculated 


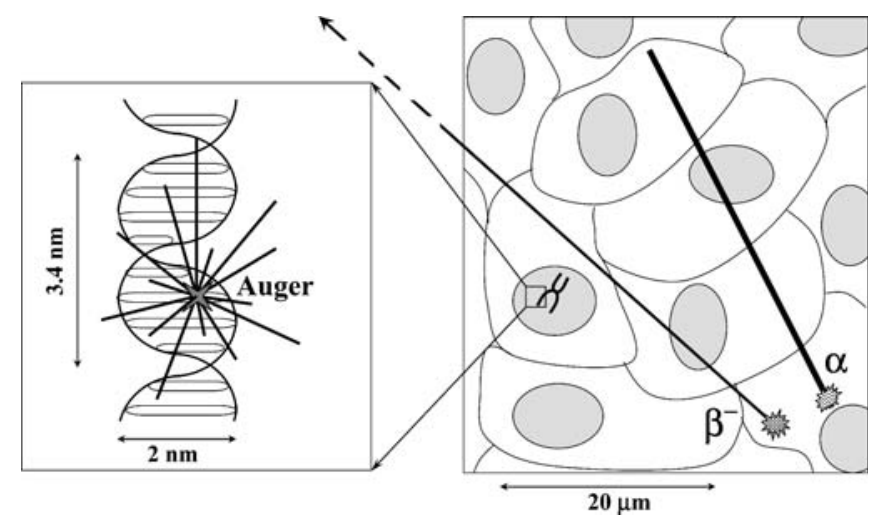

Fig. 1. Schematic presentation of $\alpha, \beta^{-}$and Auger radiation path lengths in a cellular and subcellular environment (arbitrary scaling). Note that the major energy deposition of an Auger radiation decay occurs in the close vicinity of a few nm, while that of $\alpha$ and $\beta^{-}$ radiation occurs on tracks of $40-80 \mu \mathrm{m}$ and $0.1-10 \mathrm{~mm}$, respectively

that the absorbed fraction per cell of electrons from ${ }^{90} \mathrm{Y}$ with a mean energy of $935 \mathrm{keV}$ would be as low as $0.1 \%$ [33]. In this respect, low-energy beta radiation would be more advantageous. Experimentally, superior anti-tumour efficacy was observed with somatostatin analogues labelled with a combination of a high- $\left({ }^{90} \mathrm{Y}\right)$ and lowenergy $\left({ }^{177} \mathrm{Lu}\right) \beta^{-}$emitters in rats bearing simultaneously small and large tumours [34]. More efficient systemic radiation therapies against individual tumour cells or small cell clusters, with respect to radiation deposition in the target, would be provided with $\alpha$ or Auger radiation emitters.

\section{Physical properties of Auger radiation}

Auger radiation was described in 1925 by Pierre Auger [35]. Auger electrons arise from electronic shells of radionuclides when these decay by electron capture. Electron capture processes create inner shell electron vacancies by an electron transfer from this shell into the nucleus. The inner shell electron vacancies are subsequently filled by electron transitions from shells of higher energy, a process that occurs in cascade. The energy difference of these transitions can be released either as photons or as low-energy electrons, the Auger electrons.

Typically, Auger radiation decays produce between 5 and 30 Auger electrons. Depending on the relationship of the electronic shells involved, these transitions are classified into Auger, Coster-Kronig and super-CosterKronig processes. The electrons emitted by these three processes are referred to as Auger electrons [19, 36-38].

Auger electrons are of low energy. The small negatively charged low-energy electrons produce multiple ionisations of high LET type (4-26 keV/ $\mu \mathrm{m})$ and consequently have a very short range in biological tissues, typically $<0.5 \mu \mathrm{m}$. The large majority of Auger electrons have a tissue penetration range of the order of a few nm only [19].

Internal conversion (IC) electrons are created by collision of photons (from the nuclear decay) with inner shell electrons that are ejected. IC electrons have discrete energies in the $\mathrm{keV}$ range. This energy is higher than that of most Auger electrons as defined above but lower than that of classical $\beta^{-}$radiation such as emitted by ${ }^{131} \mathrm{I}$ or ${ }^{90} \mathrm{Y}$. Some groups use a wider definition for Auger electrons, such that they comprise all low-energy electrons, and thereby consider that IC electrons are also among the Auger electrons. However, in contrast to Auger electrons, IC electrons produce mostly a low LET type tissue irradiation with a penetration path generally in the $\mu \mathrm{m}$ range. IC electrons from decays in the cytoplasm can accordingly reach the nuclear DNA. However, the observed biological efficacy of IC electrons is similar to that of conventional $\beta^{-}$radiation and X-rays [39]. When referring to IC electrons in this review, we shall call them by that name and make the distinction from Auger electrons, as justified by the different biological efficacy of these two radiation types.

A large number of radioisotopes emit some Auger radiation, but the most interesting Auger electron emitters for the purpose of treatment are ${ }^{125} \mathrm{I},{ }^{123} \mathrm{I}$ and ${ }^{201} \mathrm{Tl}$ (Table 2) [38]. ${ }^{55} \mathrm{Fe}$ would emit a very high proportion of radiation energy in the form of Auger electrons, but it does not qualify for therapy in humans owing to its half-life of 2.7 years. For the three mentioned emitters, the Auger radiation energy released per decay remains significant,

Table 1. Radiation properties of representative therapeutic radioisotopes

\begin{tabular}{|c|c|c|c|c|c|}
\hline \multirow{2}{*}{$\begin{array}{l}\text { Radiation } \\
\text { Energy }\end{array}$} & \multicolumn{3}{|l|}{$\beta^{-}$} & \multirow{2}{*}{$\begin{array}{l}\alpha \\
\text { Very high }\end{array}$} & \multirow{2}{*}{$\begin{array}{l}\text { Auger electrons } \\
\text { Very low }\end{array}$} \\
\hline & Low & Moderate & High & & \\
\hline \multirow[t]{5}{*}{ Examples } & ${ }^{169} \mathrm{Er}$ & ${ }^{131} \mathrm{I}$ & ${ }^{90} \mathrm{Y}$ & ${ }^{211} \mathrm{At}$ & ${ }^{125} \mathrm{I}$ \\
\hline & ${ }^{177} \mathrm{Lu}$ & ${ }^{186} \operatorname{Re}$ & ${ }^{188} \mathrm{Re}$ & ${ }^{213} \mathrm{Bi}$ & $123 \mathrm{I}$ \\
\hline & ${ }^{67} \mathrm{Cu}$ & ${ }^{153} \mathrm{Sm}$ & ${ }^{32} \mathrm{P}$ & ${ }^{212} \mathrm{Bi}$ & ${ }^{111} \operatorname{In}$ \\
\hline & ${ }^{199} \mathrm{Au}$ & ${ }^{111} \mathrm{Ag}$ & ${ }^{89} \mathrm{Sr}$ & ${ }^{149} \mathrm{~Tb}$ & ${ }^{55} \mathrm{Fe}$ \\
\hline & ${ }^{33} \mathrm{P}$ & ${ }^{64} \mathrm{Cu}$ & & & ${ }^{67} \mathrm{Ga}$ \\
\hline Mean tissue range (mm) & $0.1-0.3$ & $0.3-1$ & $1-5$ & $0.03-0.08$ & $<0.001$ \\
\hline Particularity & \multicolumn{3}{|c|}{ Low LET and crossfire effect } & High LET & High LET \\
\hline Best suited for treatment of: & \multicolumn{3}{|c|}{ Tumour masses } & Clusters and individual cells & Individual cells and clusters \\
\hline
\end{tabular}


Table 2. Examples of Auger electron emitters for which the Auger radiation represents a significant percentage of the overall energy release per decay

\begin{tabular}{|c|c|c|c|c|c|c|c|c|}
\hline Isotope & $\begin{array}{l}\text { Auger electrons/ } \\
\text { decay }\end{array}$ & $\begin{array}{l}\text { IC electrons/ } \\
\text { decay }\end{array}$ & $\begin{array}{l}\text { Auger } \\
\text { energy/decay } \\
(\mathrm{keV})\end{array}$ & $\begin{array}{l}\mathrm{IC} \\
\text { energy/decay } \\
(\mathrm{keV})\end{array}$ & $\begin{array}{l}\text { Total energy/ } \\
\text { decay }(\mathrm{keV})\end{array}$ & $\begin{array}{l}\text { Auger energy } \\
\text { in } \% \text { of total } \\
\text { energy/decay }\end{array}$ & $\begin{array}{l}\text { IC energy } \\
\text { in } \% \text { of total } \\
\text { energy/decay }\end{array}$ & $T_{1 / 2}$ \\
\hline${ }^{55} \mathrm{Fe}$ & 5.1 & 0 & 4.2 & 0 & 5.8 & 71.9 & 0 & $2.7 \mathrm{yr}$ \\
\hline${ }^{67} \mathrm{Ga}$ & 4.7 & 0.3 & 6.3 & 28.1 & 201.6 & 3.1 & 13.9 & $78 \mathrm{~h}$ \\
\hline $99 \mathrm{~m} \mathrm{Tc}$ & 4.0 & 1.1 & 0.9 & 15.4 & 142.6 & 0.6 & 10.8 & $6 \mathrm{~h}$ \\
\hline${ }^{111}$ In & 14.7 & 0.2 & 6.8 & 25.9 & 419.2 & 1.6 & 6.2 & $67 \mathrm{~h}$ \\
\hline $123 \mathrm{I}$ & 14.9 & 0.2 & 7.4 & 20.2 & 200.4 & 3.7 & 10.1 & $13 \mathrm{~h}$ \\
\hline${ }^{125} \mathrm{I}$ & 24.9 & 0.9 & 12.2 & 7.2 & 61.4 & 19.9 & 11.8 & $59.4 \mathrm{~d}$ \\
\hline${ }^{201} \mathrm{Tl}$ & 36.9 & 1.1 & 15.3 & 30.2 & 138.5 & 11.0 & 21.8 & $73 \mathrm{~h}$ \\
\hline
\end{tabular}

Decay energies are given as reported by the AAPM nuclear medicine task group 6 [38]. X- and $\gamma$-ray contributions are only included in the column that shows the total energy release per decay

while it is frequently less than $1 \%$ for other isotopes like ${ }^{99 \mathrm{~m}} \mathrm{Tc}$. For ${ }^{125} \mathrm{I},{ }^{123} \mathrm{I}$ and ${ }^{201} \mathrm{Tl}$, the Auger electron energy release per decay represents between $3.7 \%$ and $19.9 \%$ of the total energy, a higher proportion of radiation energy being released in the form of photons. Since photons penetrate tissue with a low energy deposition per $\mu \mathrm{m}$ path, they are of minor relevance with respect to therapy but should continue to be borne in mind for the potential nonspecific irradiation of radiosensitive tissues such as bone marrow.

The radioisotope ${ }^{123} \mathrm{I}$, though it releases only about $14 \%$ of its decay energy in the form of Auger and IC electrons, would be a good candidate for therapy. Its half-life of $13.2 \mathrm{~h}$ would be well adapted for peptide or oligonucleotide Auger radiation treatment and the biodistribution could be followed by scintigraphy based on the $\gamma$ radiation of $159 \mathrm{keV}$.

\section{Energy deposition in the nuclear space}

The shower of electrons produced in a typical Auger radiation decay has a punctiform origin. The abundance of low-energy electrons in a microscopic or "nanoscopic" space can be seen as an onion-like energy deposition in concentric spherical shells. It has been calculated that the absorbed energy around the decay site of ${ }^{125} \mathrm{I}$ would be $80 \mathrm{eV} / \mathrm{nm}^{3}$ within the first nanometre. Energy deposition would drop to about $10 \mathrm{eV} / \mathrm{nm}$ in the second nanometre ${ }^{3}$ and fall further to $3 \mathrm{eV} / \mathrm{nm}^{3}$ in the third nanometre [40]. The calculated energy deposition of $10 \mathrm{eV} / \mathrm{nm}^{3}$ within a radius of $2 \mathrm{~nm}$ implies a locally absorbed radiation dose of 1.6 MGy [40]. This local radiation dose is 22,000 times higher than a conventional external beam radiation dose of $70 \mathrm{~Gy}$ delivered in conventional radiation therapy to tumours over several weeks. The locally deposited energy of $1.6 \mathrm{MGy}$ corresponds to $1.6 \times 10^{-18} \mathrm{~J} / \mathrm{nm}^{3}$. This translates into a temperature increase of $382^{\circ} \mathrm{C} \mathrm{per} \mathrm{nm}{ }^{3}$ of water. Obviously, this locally very high energy deposition within $2 \mathrm{~nm}$ from decay will then rapidly dissipate, i.e. dilute, into the total space of the nucleus. If we consider a nucleus of $2 \mu \mathrm{m}$ radius, the dilution factor would be $10^{9}$ and the overall heating effect for the nucleus would be $0.38 \times 10^{-6 \circ} \mathrm{C}$ and thus insignificant.

\section{Auger radiation biology}

The double strand DNA helix presents a diameter of $2 \mathrm{~nm}$. In a typical Auger radiation decay, the highest energy deposition occurs in spheres of 1-2 $\mathrm{nm}$, as described elsewhere [40]. This means that the calculated local energy deposition of an Auger emitter incorporated into DNA would hit both DNA strands with an energy of 1.6 MGy or higher. This radiation energy is therefore largely sufficient to disrupt both DNA strands over distances of several nucleotides (Fig. 2) [39, 41]. For ${ }^{125} \mathrm{I}$ or ${ }^{123} \mathrm{I}$ decays associated with DNA, this translates into a general rule of: "One decay=one double strand break". Similar to an $\alpha$ radiation path through the cell nucleus, the genetic information is lost in these double strand breaks owing to destruction of several nucleotides on both strands [42-44]. Repair still remains possible but will frequently be erroneous. These features are responsible for the high RBE of Auger radiation when decays occur in close association with DNA. It is a most intriguing feature of Auger radiation that it possesses the high cytotoxicity of $\alpha$ radiation when occurring in close vicinity to DNA while being of low toxicity outside the cell nucleus.

Besides the direct effect of Auger electrons on DNA double strands, an indirect radiation effect of Auger energy deposition will occur via production of radicals [45]. The radicals diffuse freely in the intracellular space and can cause further DNA damage. Even a bystander effect by diffusion of radicals through gap junctions has been described [46].

In order to compare the RBE of different radiation types, the radiation weighting factor $\left(\mathrm{W}_{\mathrm{R}}\right)$ has been introduced. $\mathrm{W}_{\mathrm{R}}$ compares the biological efficacy of a given radiation dose of a particular radiation type with that of X-rays. $\mathrm{X}$-ray effects are being attributed the $\mathrm{W}_{\mathrm{R}}$ of $1 .{ }^{125} \mathrm{I}$ - and ${ }^{123} \mathrm{I}$ iododeoxyuridine (IdUrd) has frequently been used to 


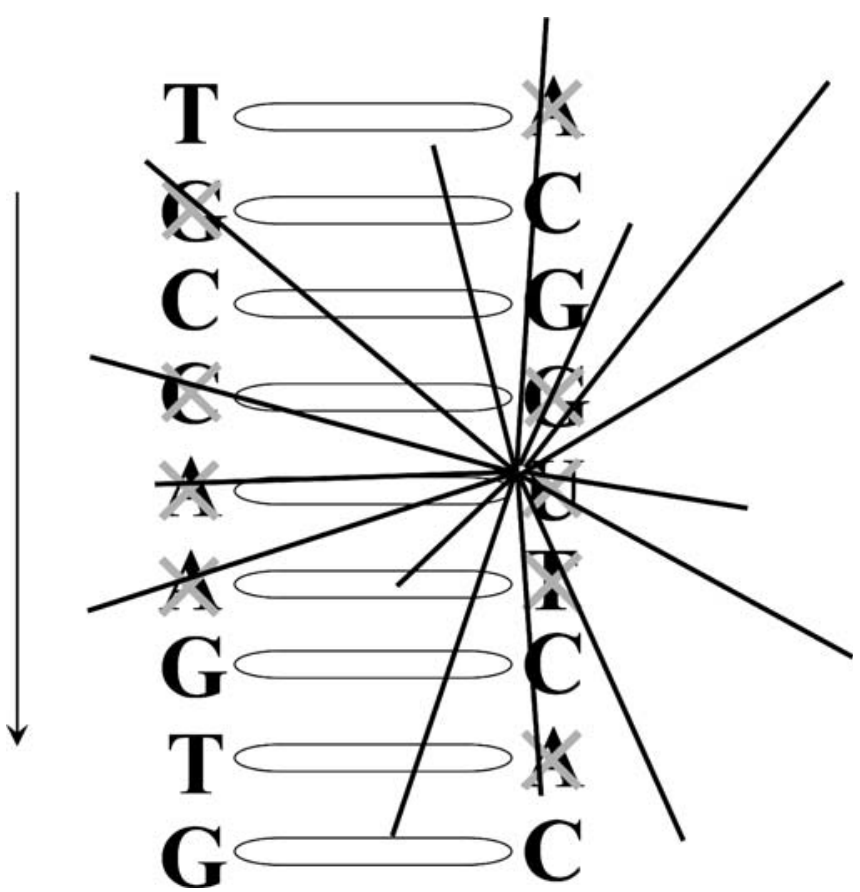

Fig. 2. Schematic presentation of an Auger radiation decay in a stretch of double strand DNA. ${ }^{125}$ I-iododeoxyuridine $\left({ }^{*} \mathrm{U}\right)$ is incorporated in DNA as a thymidine (T) analogue. The arrowhead indicates the reading direction of a given gene. The destruction of the antisense sequence guanine-iododeoxyuridine-thymidine (G-*U-T) goes together with the destruction of the sense sequence cytidineadenine-adenine (C-A-A), whereby the genetic code is lost over a stretch of three nucleotides

measure the biological effects of Auger radiation. Since the decay sites of radio-IdUrd, once incorporated into DNA, fulfil the requirement of close vicinity to DNA, double strand breaks occur with a probability of about 1 per decay. The RBE of ${ }^{125}$ I-IdUrd and ${ }^{123}$ I-IdUrd measured in V79 cells was 8 and 7 [40,47], respectively. This means that, for an identical deposition of energy, the Auger radiation of DNA-incorporated ${ }^{125}$ I-IdUrd and ${ }^{123}$ I-IdUrd would be eight- and sevenfold more efficient compared with X-rays, $\gamma$ or conventional $\beta^{-}$radiation [48]. This biological efficacy of DNA-incorporated ${ }^{123} \mathrm{I} /{ }^{125} \mathrm{I}$-IdUrd would be similar to that of $\alpha$ radiation $[48,49]$. Nuclear localised Auger processes that are not directly linked to DNA would, however, develop a $\mathrm{W}_{\mathrm{R}}$ only about half that of DNAassociated decays [39].

In experiments other than those mentioned above, different research groups have reported widely divergent biological efficacies of Auger radiation, with $\mathrm{W}_{R}$ values as high as 64 in the particular situation of chronic irradiations [50]. The appreciation of these and other reported effects remains a matter of debate [49]. The Nuclear Medicine task group of the American Association of Medical Physicists has proposed the application of a radiation weighting factor of 10 for deterministic effects of Auger radiation and a factor of 20 for stochastic effects, provided that this radiation occurs in the nucleus in close association with DNA [39]. In view of the mentioned divergent observations, this proposal is not generally accepted.
Unlike most Auger electrons, IC electrons may significantly irradiate the cell nucleus when decaying in the cytoplasm. Because of the lower biological efficacy of IC electrons, however, the predicted radiation effects must be clearly distinguished between IC and Auger electrons, notably when the latter occur in the nucleus. As previously mentioned, such IC electrons develop a low LET type irradiation associated with mostly single strand breaks and a $\mathrm{W}_{\mathrm{R}}$ of about 1 [39].

\section{Gonadal effects}

It is quite well established that Auger irradiation of the gonads also gives an RBE of about 7 regarding deterministic effects [51]. However, the stochastic effects of Auger radiation emitters in human gonads remain a question of debate. There are divergent observations concerning not only long term effects but also the calculation of dose deposition in gonad cells. It has been reported that the irradiation dose to sperm heads may be up to 160 times higher than that cited by ICRP report 53, which did not include Auger radiation [52]. Furthermore, transfer of ${ }^{111} \mathrm{In}$ labelled transferrin through the intact, so-called blood-testis barrier has been reported, which would be mediated by the Sertoli cells $[53,54]$. The authors referred to evidence from experimental animal studies that the emitted Auger radiation might even produce hereditary effects in offspring [55]. It could be hypothesised that similar situations would be found in ovaries, since separation of the maternal and offspring circulation would provide a barrier similar to that in male gonads. As a consequence of these observations, these authors [55] suggested that the administration of larger diagnostic activities of ${ }^{111}$ In-radiopharmaceuticals might require contraception. In comparison, our first experiments with ${ }^{125} \mathrm{I}$-IdUrd did not indicate any significant uptake into gonads of mice. This suggested that the blood-testis barrier might be operational for this agent as well. This statement would be in agreement with the observation that radio-IdUrd does not cross the intact blood-brain barrier [56]. However, autoradiographic experiments have not been performed in these studies, which represents a limitation.

\section{Bystander effect}

It has been reported that an in vivo bystander effect occurred in experiments using mixtures of ${ }^{125}$ I-IdUrd-labelled LS174T cells and untreated cells [57]. The existence of such an effect would allow therapy to be envisaged even if not all cancer cells were targeted with a given radiopharmaceutical. In the mentioned experiments, the mixed cell suspensions containing defined proportions of ${ }^{125}$ I-IdUrd pre-labelled cells and a constant amount of unlabelled cells were injected subcutaneously in nude mice and tumour outgrowth was followed 10-15 days later. It appeared that the radiolabelled, dying cells developed a growth inhibitory effect on the non-pre-labelled cells, producing a tumour growth delay 2-4 days longer than expected. It was also 
shown that the growth delay could not be explained by a minor radiation exposure of non-pre-labelled cells from the $\gamma$-radiation of ${ }^{125} \mathrm{I}$, since much higher external beam irradiation doses were required to diminish tumour growth to a similar degree. The authors thus concluded that an Auger radiation therapy effect was observed which involved more than just the tumour cells that were pre-labelled. Whether this observation in fresh transplanted cells can be extrapolated directly to outgrown tumours targeted with Auger radiation emitters remains to be shown.

\section{Dosimetry}

Biodistribution and kinetic measurements of internal radiopharmaceuticals in patients are difficult to achieve. A high-quality dosimetry of $\gamma$ - or positron-emitting radiopharmaceuticals remains most difficult to perform in a standard clinical setting [58]. The task becomes close to unrealistic on an individual patient basis for Auger radiation emitters. For Auger radiation dosimetry, knowledge of the percentage of cells that are targeted in individual tissues is essential. Furthermore, most relevant Auger irradiation would occur only for DNA-associated emitters [39, 59]. In contrast to target cells, non-target cells would not be, or would be only minimally, irradiated from Auger electron decays.

Given that the cumulated organ activity is known, a mean nuclear absorbed radiation dose may be calculated, if the percentage of DNA-associated Auger radiation can be estimated. S values for such situations have been provided [60]. For the estimation of the risk of long-term stochastic effects, a $W_{R}$ of 20 may then be applied for nuclearassociated Auger radiation [39]. This may provide a radiation dose risk estimate for a patient exposed to Auger radiation in a nuclear medicine diagnostic procedure [61]. As a best approximation, this dosimetry was based on biodistribution and DNA incorporation measurements performed in mice [61]. Measurement of all these parameters in individual patients would be impossible. Such risk appreciation should, however, be taken seriously, particularly if significant uptake of the radiopharmaceutical occurs in the gonads. As mentioned, if an Auger radiopharmaceutical is taken up by the gonads, the cellspecific localisation would have to clearly distinguish between germline and stromal cell localisation in order to allow for adequate Auger radiation dosimetry.

For calculation of deterministic, cytotoxic effects of Auger radiation, knowledge of a mean nuclear absorbed radiation dose in an organ, however, is insufficient. Here, it is essential to have an estimate of the percentage of cells that are targeted and to know the uptake rate of the radiopharmaceutical into these cells. Furthermore, considering the effects of Auger radiation emitters with a long half-life, such as ${ }^{125}$ I, cells insufficiently targeted might escape cytotoxicity through cell division [36]. Cell division produces a dilution of Auger radiation decays into multiple daughter cells. Furthermore, considering clonal survival, the probability of survival of at least one out of several daughter cells will be higher than that of a single parent cell exposed to the same number of Auger decays. The precise dosimetric handling of cell division during long-lasting Auger radiation is therefore highly complex. It requires, in addition to the mentioned considerations, attention to the notion of cell division delay [62] due to continued irradiation that causes double strand DNA breaks. Double strand beaks in turn induce cycling stop signals at different check-points of the cell cycle allowing repair.

Biological Auger radiation effects have frequently been measured with ${ }^{125} \mathrm{I}$ or ${ }^{123} \mathrm{I}$-IdUrd. The short, 13-h half-life of ${ }^{123}$ I provides an Auger radiation emitter that delivers the large majority of its irradiation within 1 day, while cellular doubling of tumours frequently occurs within 1 to several days. In contrast, due to the long, 60-day half-life, ${ }^{125} \mathrm{I}$, radiation delivery will occur over several days or weeks provided that the radiopharmaceutical remains associated with DNA. It was calculated for ${ }^{125}$ I-IdUrd that a given cell was sterilised with a mean of 120 Auger radiation decays that occurred in close association with DNA [62]. This would correspond to about 120 DNA double strand breaks. This calculation was based on the knowledge of a normal cell division time as well as a division time under a given Auger irradiation condition. Thus, the out-dilution effect of ${ }^{125}$ I-IdUrd during cell division was taken into account in this dosimetry. However, in our understanding, the creation of two or multiple daughter cells with an accordingly higher clonal survival probability compared with a single cell has not been included in the mentioned calculations [36, 62]. Overall, the above-mentioned number of 120 Auger decays that would kill a cell therefore remains an estimate and applicable to the particular cell line only.

\section{Radioprotection}

In view of the difficulty of precise Auger radiation dosimetry, radioprotection in this field requires the application of a large factor of potential overprotection in order to cover the uncertainties from the dose calculation. For any given Auger electron-emitting radiopharmaceutical, a potential localisation in the cell nucleus of bone marrow stem cells or, notably, germinal cells should be of the utmost concern. This could be the case for oligonucleotides, ${ }^{125} \mathrm{I}-$ IdUrd or other nucleotides as well as hormones. However, nuclear localisation might also occur with other radiopharmaceuticals, as has been described for ${ }^{111}$ In-labelled pharmaceuticals $[53,54]$. According to these authors, ${ }^{111} \mathrm{In}$ might be released from a radiopharmaceutical and be transported into gonad cells via binding to transferrin.

\section{Experimental treatment approaches}

\section{Hormones and growth factors}

Steroid hormones and analogues localise to nuclear receptors $[63,64]$. An advantage of hormonal vectors is 
the fact that all tumour cells are potential targets. ${ }^{123} \mathrm{I}-$ and ${ }^{125}$ I-iodo-oestrogens were used to study Auger radiation treatment of oestrogen receptor-positive MCF-7 breast cancer cells [65-67]. The authors determined the dose producing on average one lethal event per cell, the $D_{37}$. The random distribution of one lethal event per cell predicts that $37 \%$ of cells will survive, as calculated by a Gaussian model [17]. This leads to the definition of the term $D_{37}$ as the percent of survival corresponding to a mean of one lethal hit per cell. These authors determined a $D_{37}$ of 28 decays/cell for ${ }^{125}$ I-oestrogen. Similarly, for ${ }^{125}$ I-IdUrd the $\mathrm{D}_{37}$ was determined as 30 decays/cell. In these experiments, cells were frozen in order to accumulate the number of decays/cell, facilitating dosimetry calculations without interference from cell division. In terms of biological efficacy, these numbers of decays would correspond to an RBE of about 4.5. However, freezing as an artificial event might itself modulate the survival probability after a given cell insult and the biological relevance of this determination of $D_{37}$ might therefore not be definitive.

Epidermal growth factor (EGF) has been labelled with ${ }^{111}$ In-DTPA. It was reported that after an incubation period of $24 \mathrm{~h}$ up to $9.6 \%$ of the conjugate was found associated with nuclear chromatin of breast cancer cells overexpressing the EGF receptor [68]. Growth inhibition was observed in a corresponding tumour xenograft model [69].

With regard to ${ }^{111}$ In-DTPA-labelled octreotide, autoradiographic in vitro experiments showed that a small fraction was being incorporated into the cell nucleus of receptor-positive cells [70]. With the aim of increasing the affinity to receptors, experimental studies with different somatostatin analogues have been performed, including recently a tri-functional peptide [71]. Based on the observation of partial intranuclear localisation and evidence of therapeutic efficacy in rats, ${ }^{111}$ In-DTPA-octreotide has been evaluated in clinical studies for therapy of neuroendocrine tumours [72-75], as discussed below.

\section{Radio-iododeoxyuridine (IdUrd)}

Radiolabelled iododeoxyuridine, such as ${ }^{125} \mathrm{I}-$ and ${ }^{123} \mathrm{I}-$ IdUrd, has been studied for many years for its Auger radiation effects [19]. The fact that these thymidine analogues are directly incorporated into nascent DNA during the synthesis phase of the cell cycle provides a most reliable model for the experimental measurement of Auger radiation biological effects.

A first major restriction of radiolabelled nucleotides, however, lies in the fact that they are incorporated into DNA only during the synthesis phase of the cell cycle. This restriction has generally been overcome in vitro by using incubation times covering at least two to three cell cycles. For in vivo applications, osmotic pumps delivering radioIdUrd continuously over several days have been used in order to bypass the problem of the very short circulation time of nucleotides that are rapidly degraded after administration.
A low rate of DNA incorporation both in vitro and in vivo constitutes a second significant problem with the use of ${ }^{125} \mathrm{I}$ - or ${ }^{123} \mathrm{I}$-IdUrd. There are two obvious major reasons for this: first, rapid catabolism of IdUrd and second, competition from endogenous thymidine (dThd). In order to circumvent the low DNA incorporation rate of ${ }^{125} \mathrm{I}$ and ${ }^{123}$ I-IdUrd, incorporation modulation using dThd synthesis inhibition has been studied by several groups [76-78]. The aim has been to take advantage, under blocked endogenous dThd synthesis, of the preferential incorporation of radio-IdUrd into DNA through the salvage pathway. The combination with different dThd synthesis inhibitors, such as fluorodeoxyuridine (FdUrd) or methotrexate, produced up to a fivefold increase in the incorporation rates of unlabelled or radiolabelled IdUrd or bromodeoxyuridine [76-78]. However, the increase in incorporation after dThd synthesis inhibition did not yield the expected increase in therapeutic efficacy of radio-IdUrd [77]. The reason for the absence of an increase in toxicity corresponding to the increased DNA incorporation rate of ${ }^{125}$ I-IdUrd after dThd synthesis inhibition remains unexplained, to our knowledge.

We used the approach of short exposure of radio-IdUrd in combination with short, non-toxic exposure to FdUrd. We first showed that ${ }^{125}$ I-IdUrd incorporation in DNA increased with this approach multiple-fold both in vitro and in vivo using three different glioblastoma cell lines and tumours [79]. After direct intra-tumoural application, up to $20 \%$ of radio-IdUrd was incorporated into tumour cell DNA after FdUrd pre-treatment [80]. In comparison, only $4 \%$ of injected activity was DNA incorporated in non-pretreated animals. In the next step, we improved targeting of radio-IdUrd into a higher number of cells. After the nontoxic pre-treatment with FdUrd, cell synchronisation into early $\mathrm{S}$ phase was observed for the different cell lines studied $16-24 \mathrm{~h}$ post FdUrd. Thus $\geq 70 \%$ of glioblastoma cells were synchronised in S phase and incorporated high amounts of radio-IdUrd [81] at these delayed times. In our most recent experiments, we were able to show that $70-80 \%$ of glioblastoma cells were killed after a single incubation with modest activities of ${ }^{125}$ I-IdUrd after FdUrd pre-treatment, whereas maximally $30 \%$ of cells were killed after exposure to ${ }^{125}$ I-IdUrd alone, even when using much higher concentrations. These percentages thus correlate with the percentage of $\mathrm{S}$ phase cells targeted after FdUrd pre-treatment.

In vivo, prolonged TS inhibition has been observed after treatment with 5-fluorouracil [82]. Furthermore, i.v. push injection of FdUrd is overall of low toxicity and has been used therapeutically in the early stage of clinical application of FdUrd [83, 84]. In comparison, the maximal tolerated dose (MTD) of continued exposure $(0.15 \mathrm{mg} / \mathrm{kg}$ FdUrd perfused per day) is about 200-fold lower than the MTD of FdUrd given in a single i.v. push injection $(30 \mathrm{mg} / \mathrm{kg}$ per day). These data suggest that the approach of FdUrdinduced cell synchronisation might be used in vivo to deliver radio-IdUrd to a high percentage of tumour cells.

As another parameter of radio-IdUrd biology, the function of nucleoside transporters has occasionally been 
studied [85]. Certain subtypes of nucleoside transporters are known to be expressed in a cell cycle-dependent manner. Thus, hCNT1 is increased in $\mathrm{G}_{1}-\mathrm{S}$ transition [86]. It has been shown that inhibition of thymidylate synthase leads to multiple-fold (30-fold) up-regulation of nucleoside transporter expression [85]. This observation appears compatible with the description of increased hCNT1 expression in the synthesis phase of the cell cycle [86]. In our opinion, such a regulation feedback would favour cell uptake and incorporation of exogenous nucleosides under the condition of suppressed endogenous dThd synthesis and might represent a key element in certain Auger radiation therapy approaches, such as intra-tumoural injection of radio-IdUrd.

\section{Oligonucleotides}

Targeting of specific sequences of DNA or mRNA with triplex-forming oligonucleotides $[44,87,88]$ or antisense oligonucleotides $[89,90]$ is a further appealing perspective of Auger radiation treatment. The strategy aims to target Auger radiation into key elements of cell survival. Targeting of genes that are overexpressed in tumours would be most interesting. As with nucleotides, however, this strategy faces the obstacles of oligonucleotide instability and low rates of uptake into the nuclear target. The transfer of the oligonucleotides from the cytoplasm into the nuclear compartment is generally very limited and appears to be controlled by cellular elements that have not been identified [44].

Aptamers represent another class of DNA or RNA oligonucleotides. Aptamers fold into unique tertiary conformations that are capable of binding most diverse target antigens with high affinity and specificity, analogous to antibodies [91-93]. Tumour targeting with a radiolabelled aptamer has been demonstrated [94]. This opens the possibility of using them in an internal radiotherapy strategy. However, in common with the other oligonucleotides, the in vivo half-lives of aptamers are generally short. Different stabilisation strategies have therefore been attempted to overcome this limitation [92, 95-97].

Oligonucleotides can target mRNA in cytoplasm and in the nucleus. Auger radiation delivered with antisense oligonucleotides might be a means to disrupt mRNA and thus be aimed at reducing translation of particular genes. This approach could therefore be a means of circumventing the problem of low uptake into the nuclear space. Similarly, aptamers can directly target gene products in cytoplasm and coupling with Auger emitters could potentially be a means to increase their efficacy.

\section{Low-energy electrons targeted into cytoplasm}

Different monoclonal antibodies elicit antigen internalisation upon binding. Such antibodies have been labelled with ${ }^{125} \mathrm{I}$ and other Auger or low-energy electron emitters [98-102]. Two-step targeting has been used in this approach as well [103]. Similarly, MIBG, as an analogue of noradrenaline, is concentrated in adrenergic tumour cells and can be labelled with the different iodine radio-isotopes for treatment purposes [104]. ${ }^{125}$ I-labelled MIBG has been used in an Auger/low-energy electron therapy approach [105]. The fraction of intracellular generated electrons from ${ }^{125} \mathrm{I}$ decays (18-keV electrons) that is absorbed by individual cells has been calculated to be as high as $60 \%$. In comparison, the absorbed fraction per cell of electrons from ${ }^{90} \mathrm{Y}$, with a mean energy of $935 \mathrm{keV}$, would be as low as $0.1 \%$ [33]. Other low-energy electron emitters have also been proposed for targeting of small tumour cell clusters, such as ${ }^{58} \mathrm{Co}$ and ${ }^{103 \mathrm{~m}} \mathrm{Rh}$ [106] or ${ }^{67} \mathrm{Ga}$ - and ${ }^{111}$ In-labelled compounds [102].

${ }^{125}$ I-iodide has been explored for therapy of hyperthyroidism and thyroid cancer [107-111]. However, no significant advantage could be observed as compared with ${ }^{131}$ I therapy. Radio-targeted gene therapy is a similar approach whereby new genes are introduced into a tumour, allowing cellular uptake of Auger radiopharmaceuticals. Tumour transfection with the sodium iodide symporter followed by treatment with ${ }^{125} \mathrm{I}$ could constitute such a low-energy electron radiation therapy approach $[112,113]$. The biological efficacy to be expected from such approaches will be similar to that of X-rays for an identical radiation dose deposition.

\section{Clinical studies}

Treatment studies of thyroid cancer and hyperthyroidism have been performed with ${ }^{125} \mathrm{I}[108-111]$. The combination of longer range, low-energy, $\gamma$ radiation with the shortrange Auger and IC electron effects of ${ }^{125} \mathrm{I}$ could be a means to treat both large and small cancer nodules or hyperplastic thyroid tissue. The efficacy of ${ }^{125}$ I treatment, however, has been limited. The fact that radio-iodine does not enter the nucleus and stays only briefly in the cytoplasm before being deposited in colloidal form might be responsible for the low contribution of Auger effects in treatment. In fact, only a minor portion of the low-energy electrons from ${ }^{125}$ I decay in cytoplasm and particularly in colloid can reach the nuclear DNA. Furthermore, the radiation protection issues of ${ }^{125} \mathrm{I}$ are difficult to handle in the clinical setting because of its long half-life of 60 days and continued urinary elimination.

Most advanced therapy studies have been performed with ${ }^{111}$ In-DTPA labelled octreotide [72, 73]. Here, nuclear localisation of ${ }^{111}$ In-octreotide had been described, though the percentage entering the nucleus might be small overall [70]. A direct Auger radiation effect on DNA was therefore expected. Studies were performed on more than 50 patients, but efficacy was rather modest. Therapeutic effects after injection of $20-160 \mathrm{GBq}{ }^{111}$ In-DTPA-octreotide consisted mostly in stabilisation of tumour growth, partial remissions remaining scarce. Bone marrow toxicity was generally mild; however, two myelodysplastic syndromes and one case of leukaemia were observed in a group of six patients who had been treated with a total of more than $100 \mathrm{GBq}{ }^{111}$ In-DTPA- 
octreotide [74, 75]. This latter observation was rather unexpected. A word of caution was expressed by the authors, who suggested that cumulated activities of ${ }^{111}$ Inpeptide conjugates should not exceed $100 \mathrm{GBq}$. A dosimetric calculation for these clinical therapy studies has not been presented, to our knowledge. Insufficient knowledge of biodistribution and subcellular localisation of the Auger radiation emitter might have been responsible for this omission. The reason for the limited efficacy of these treatments therefore remains a matter of speculation. In fact, it was observed that the distribution of radiotracer was quite inhomogeneous in kidney [114]. Similar inhomogeneous distribution of radiotracer might have occurred in tumour and have been partially responsible for the limited therapeutic efficacy. In more recent studies, these groups based their systemic radiation therapy of neuroendocrine tumours on $\beta^{-}$emitters using ${ }^{90} \mathrm{Y}-$ or ${ }^{177} \mathrm{Lu}$-labelled somatostatin analogues [75].

Clinical studies with radio-IdUrd have been performed, mostly with the aim of measuring and visualising tumour targeting [56, 115-118]. Multiple injections or prolonged perfusion was not used in these rather preparative clinical approaches. The requirement that tumour therapy with Auger electron emitters should target a high percentage of all cancerous cells was therefore not met. As a consequence, therapeutic efficacy was generally not observed in these studies.

Antibodies directed against different tumour-associated antigens might elicit antigen internalisation upon binding. Such antibodies have been labelled with ${ }^{125} \mathrm{I}$ and other Auger or low-energy electron emitters, and first therapy studies been performed in patients [98, 119]. Similarly, ${ }^{125}$ I-labelled MIBG has been used in an Auger/low-energy electron therapy approach [105]. Therapeutic efficacy with these latter agents was mostly modest. In fact, also in radioMIBG treatment, ${ }^{131} \mathrm{I}$ is still the preferred radioisotope for therapeutic applications [104]. As for radioimmunotherapy of solid tumours based on $\beta^{-}$emitters, bone marrow toxicity has been revealed as the dose-limiting factor for antibodies labelled with Auger radiation emitters. Furthermore, and similar to thyroid treatment with ${ }^{125} \mathrm{I}$, the internalising antibodies do not enter the nucleus. The Auger radiation therefore reaches the nucleus only partially, and its biological efficacy will be modest, with a $\mathrm{W}_{\mathrm{R}}$ of about 1 [39].

Overall, clinical studies with Auger radiation emitters have not met the major goal of efficacy, but some of these studies have been performed with the aim of gaining knowledge as to the feasibility of such an approach, rather than with a therapeutic objective. Once the problems have been solved, however, the particular properties of Auger radiation will make its use for therapy an attractive proposition.

\section{Conclusion}

Targeting of Auger or IC electron emitters into the nucleus or cytoplasm of tumour cells is an appealing approach for systemic radiation therapy. Multiple obstacles to the administration of such therapies have been recognised and some of them have been partially overcome. However, most of these approaches still await demonstration of successful use in animal models, which will be essential prior to clinical application. Better understanding of Auger radiation dosimetry and of its biological efficacy remains another major task. The latter must guide our therapy research, but in addition information must be gathered on many radiopharmaceuticals that can reach the cell nuclei with potential harmful Auger radiation. The combination of these efforts may allow the potential health risk of this particular radiation type to be assessed and may also guide research in an appropriate way towards tumour therapy.

Acknowledgements. Preparation of this article was made possible within the frame of research grants from the Swiss National Science Foundation, Nos. 31-67112.01 and 3100AO-110023/1. We also express our gratitude to Mrs. Frances Godson for reviewing the manuscript

\section{References}

1. Larson SM, Krenning EP. A pragmatic perspective on molecular targeted radionuclide therapy. J Nucl Med 2005;46 Suppl $1: 1 \mathrm{~S}-3 \mathrm{~S}$

2. Schlumberger MJ. Papillary and follicular thyroid carcinoma N Engl J Med 1998;338:297-306

3. Feinendegen LE. Contributions of nuclear medicine to the therapy of malignant tumors. J Cancer Res Clin Oncol 1993;119:320-322

4. Boelaert K, Franklyn JA. Sodium iodide symporter: a novel strategy to target breast, prostate, and other cancers? Lancet 2003;361:796-797

5. Berlin NI, Wasserman LR. Polycythemia vera: a retrospective and reprise. J Lab Clin Med 1997;130:365-373

6. Finlay IG, Mason MD, Shelley M. Radioisotopes for the palliation of metastatic bone cancer: a systematic review. Lancet Oncol 2005;6:392-400

7. Liepe K, Runge R, Kotzerke J. Systemic radionuclide therapy in pain palliation. Am J Hosp Palliat Care 2005;22:457-464

8. Bauman G, Charette M, Reid R, Sathya J. Radiopharmaceuticals for the palliation of painful bone metastasis - a systemic review. Radiother Oncol 2005;75:258-270

9. Mach JP, Carrel S, Merenda C, Sordat B, Cerottini JC. In vivo localisation of radiolabelled antibodies to carcinoembryonic antigen in human colon carcinoma grafted into nude mice. Nature 1974;248:704-706

10. Primus FJ, Wang RH, Goldenberg DM, Hansen HJ. Localization of human GW-39 tumors in hamsters by radiolabeled heterospecific antibody to carcinoembryonic antigen. Cancer Res 1973;33:2977-2982

11. Goldenberg DM. Advancing role of radiolabeled antibodies in the therapy of cancer. Cancer Immunol Immunother 2003;52:281-296

12. Juweid ME. Radioimmunotherapy of B-cell non-Hodgkin's lymphoma: from clinical trials to clinical practice. J Nucl Med 2002;43:1507-1529

13. Otte A, Jermann E, Behe M, Goetze M, Bucher HC, Roser HW, et al. DOTATOC: a powerful new tool for receptor-mediated radionuclide therapy. Eur J Nucl Med 1997;24:792-795 
14. Otte A, Mueller-Brand J, Dellas S, Nitzsche EU, Herrmann R, Maecke HR. Yttrium-90-labelled somatostatin-analogue for cancer treatment. Lancet 1998;351:417-418

15. Couturier O, Supiot S, Graef-Mougin M, Faivre-Chauvet A, Carlier T, Chatal JF, et al. Cancer radioimmunotherapy with alpha-emitting nuclides. Eur $\mathrm{J}$ Nucl Med Mol Imaging 2005;32:601-614

16. Mulford DA, Scheinberg DA, Jurcic JG. The promise of targeted \{alpha\}-particle therapy. J Nucl Med 2005;46 Suppl 1:199S-204S

17. Thames HD, Hendry JH. Fractionation in radiotherapy. 1st edn. London: Taylor and Francis, 1987

18. DeNardo GL, Schlom J, Buchsbaum DJ, Meredith RF, O'Donoghue JA, Sgouros G, et al. Rationales, evidence, and design considerations for fractionated radioimmunotherapy. Cancer 2002;94:1332-1348

19. Kassis AI, Adelstein SJ. Radiobiologic principles in radionuclide therapy. J Nucl Med 2005;46:4S-12S

20. Valerie K, Povirk LF. Regulation and mechanisms of mammalian double-strand break repair. Oncogene 2003;22:5792-5812

21. Vilenchik MM, Knudson AG. Endogenous DNA double-strand breaks: production, fidelity of repair, and induction of cancer. Proc Natl Acad Sci USA 2003;100:12871-12876

22. De Jong M, Kwekkeboom D, Valkema R, Krenning EP. Radiolabelled peptides for tumour therapy: current status and future directions. Plenary lecture at the EANM 2002. Eur J Nucl Med Mol Imaging 2003;30:463-469

23. Fisher RI, Kaminski MS, Wahl RL, Knox SJ, Zelenetz AD, Vose JM, et al. Tositumomab and iodine-131 tositumomab produces durable complete remissions in a subset of heavily pretreated patients with low-grade and transformed nonHodgkin's lymphomas. J Clin Oncol 2005;23:7565-7573

24. Gordon LI, Molina A, Witzig T, Emmanouilides C, Raubitschek A, Darif M, et al. Durable responses after ibritumomab tiuxetan radioimmunotherapy for $\mathrm{CD} 20+\mathrm{B}$-cell lymphoma: long-term follow-up of a phase I/II study. Blood 2004;103:4429-4431

25. Press OW, Rasey J. Principles of radioimmunotherapy for hematologists and oncologists. Semin Oncol 2000;27:62-73

26. Faderl S, Coutre S, Byrd JC, Dearden C, Denes A, Dyer MJ, et al. The evolving role of alemtuzumab in management of patients with CLL. Leukemia 2005;19:2147-2152

27. McLaughlin P, Grillo-Lopez AJ, Link BK, Levy R, Czuczman MS, Williams ME, et al. Rituximab chimeric anti-CD20 monoclonal antibody therapy for relapsed indolent lymphoma: half of patients respond to a four-dose treatment program. J Clin Oncol 1998; 16:2825-2833

28. Neyt M, Albrecht J, Cocquyt V. An economic evaluation of Herceptin in adjuvant setting: the Breast Cancer International Research Group 006 trial. Ann Oncol 2006;17:381-390

29. Trümper L. Radioimmuntherapie in der Hämatologie und Onkologie. 1st edn. Bremen: Uni-Med Science, 2005

30. O'Donoghue JA, Bardies M, Wheldon TE. Relationships between tumor size and curability for uniformly targeted therapy with beta-emitting radionuclides. J Nucl Med 1995;36:1902-1909

31. Vogel CA, Galmiche MC, Buchegger F. Radioimmunotherapy and fractionated radiotherapy of human colon cancer liver metastases in nude mice. Cancer Res 1997;57:447-453

32. Sharkey RM, Weadock KS, Natale A, Haywood L, Aninipot R, Blumenthal RD, et al. Successful radioimmunotherapy for lung metastasis of human colonic cancer in nude mice. J Natl Cancer Inst 1991;83:627-632

33. Hindorf C, Emfietzoglou D, Linden O, Kostarelos K, Strand SE. Internal microdosimetry for single cells in radioimmunotherapy of B-cell lymphoma. Cancer Biother Radiopharm 2005;20:224-230
34. De Jong M, Breeman WA, Valkema R, Bernard BF, Krenning EP. Combination radionuclide therapy using ${ }^{177} \mathrm{Lu}-$ and ${ }^{90} \mathrm{Y}-$ labeled somatostatin analogs. J Nucl Med 2005;46 Suppl $1: 13 \mathrm{~S}-17 \mathrm{~S}$

35. Auger P. Sur les rayons beta secondaires produits dans un gaz par des rayons X. Comp Rend 1925;180:65-68

36. O'Donoghue JA, Wheldon TE. Targeted radiotherapy using Auger electron emitters. Phys Med Biol 1996;41:1973-1992

37. Sastry KS. Biological effects of the Auger emitter iodine-125: a review. Report No. 1 of AAPM Nuclear Medicine Task Group No. 6. Med Phys 1992;19:1361-1370

38. Howell RW. Radiation spectra for Auger-electron emitting radionuclides: report No. 2 of AAPM Nuclear Medicine Task Group No. 6. Med Phys 1992;19:1371-1383

39. Humm JL, Howell RW, Rao DV. Dosimetry of Auger-electronemitting radionuclides: report no. 3 of AAPM Nuclear Medicine Task Group No. 6. Med Phys 1994;21:1901-1915

40. Kassis AI, Fayad F, Kinsey BM, Sastry KS, Taube RA, Adelstein SJ. Radiotoxicity of ${ }^{125} \mathrm{I}$ in mammalian cells. Radiat Res 1987;111:305-318

41. Howell RW, Narra VR, Sastry KS, Rao DV. On the equivalent dose for Auger electron emitters. Radiat Res 1993;134:71-78

42. Lobachevsky PN, Martin RF. Iodine-125 decay in a synthetic oligodeoxynucleotide. I. Fragment size distribution and evaluation of breakage probability. Radiat Res 2000;153:263-270

43. Lobachevsky PN, Karagiannis TC, Martin RF. Plasmid DNA breakage by decay of DNA-associated Auger electron emitters: approaches to analysis of experimental data. Radiat Res 2004;162:84-95

44. Panyutin IG, Neumann RD. The potential for gene-targeted radiation therapy of cancers. Trends Biotechnol 2005;23: 492-496

45. Bishayee A, Rao DV, Howell RW. Radiation protection by cysteamine against the lethal effects of intracellularly localized Auger electron, alpha- and beta-particle emitting radionuclides. Acta Oncol 2000;39:713-720

46. Bishayee A, Hill HZ, Stein D, Rao DV, Howell RW. Free radical-initiated and gap junction-mediated bystander effect due to nonuniform distribution of incorporated radioactivity in a three-dimensional tissue culture model. Radiat Res 2001;155:335-344

47. Makrigiorgos GM, Kassis AI, Baranowska-Kortylewicz J, McElvany KD, Welch MJ, Sastry KS, et al. Radiotoxicity of $5-[123$ I] iodo-2'-deoxyuridine in V79 cells: a comparison with 5-[ ${ }^{125}$ I] iodo-2'-deoxyuridine. Radiat Res 1989;118:532-544

48. Rao DV, Narra VR, Howell RW, Govelitz GF, Sastry KS. Invivo radiotoxicity of DNA-incorporated ${ }^{125}$ I compared with that of densely ionising alpha-particles. Lancet 1989;2:650-653

49. Pomplun E, Booz J, Dydejczyk A, Feinendegen LE. A microdosimetric interpretation of the radiobiological effectiveness of ${ }^{125} \mathrm{I}$ and the problem of quality factor. Radiat Environ Biophys 1987;26:181-188

50. Howell RW, Rao DV, Hou DY, Narra VR, Sastry KS. The question of relative biological effectiveness and quality factor for Auger emitters incorporated into proliferating mammalian cells. Radiat Res 1991;128:282-292

51. Narra VR, Howell RW, Harapanhalli RS, Sastry KS, Rao DV. Radiotoxicity of some iodine-123, iodine-125 and iodine-131labeled compounds in mouse testes: implications for radiopharmaceutical design. J Nucl Med 1992;33:2196-2201

52. Hoyes KP, Nettleton JS, Lawson RS, Morris ID. Transferrindependent uptake and dosimetry of Auger-emitting diagnostic radionuclides in human spermatozoa. J Nucl Med 1998;39:895-899

53. Hoyes KP, Morris ID, Hendry JH, Sharma HL. Transferrinmediated uptake of radionuclides by the testis. J Nucl Med 1996;37:336-340 
54. Hoyes KP, Johnson C, Johnston RE, Lendon RG, Hendry JH, Sharma HL, et al. Testicular toxicity of the transferrin binding radionuclide ${ }^{114 \mathrm{~m}} \mathrm{In}$ in adult and neonatal rats. Reprod Toxicol 1995;9:297-305

55. Hoyes KP, Lord BI, McCann C, Hendry JH, Morris ID. Transgenerational effects of preconception paternal contamination with (55)Fe. Radiat Res 2001;156:488-494

56. Blasberg RG, Roelcke U, Weinreich R, Beattie B, von Ammon $\mathrm{K}$, Yonekawa $\mathrm{Y}$, et al. Imaging brain tumor proliferative activity with ${ }^{124}$ I] iododeoxyuridine. Cancer Res 2000;60:624-635

57. Xue LY, Butler NJ, Makrigiorgos GM, Adelstein SJ, Kassis AI. Bystander effect produced by radiolabeled tumor cells in vivo. Proc Natl Acad Sci USA 2002;99:13765-13770

58. Sgouros G. Dosimetry of internal emitters. J Nucl Med 2005;46 Suppl 1:18S-27S

59. Stabin MG, Howell RW, Colas-Linhart NC. Modeling radiation dose and effects from internal emitters in nuclear medicine: from the whole body to individual cells. Cell Mol Biol (Noisy-legrand) 2001;47:535-543

60. Goddu SM, Howell RW, Rao DV. Calculation of equivalent dose for Auger electron emitting radionuclides distributed in human organs. Acta Oncol 1996;35:909-916

61. Buchegger F, Vieira JM, Blaeuenstein P, Dupertuis YM, Schaffland AO, Grannavel C, et al. Preclinical Auger and gamma radiation dosimetry for fluorodeoxyuridine-enhanced tumour proliferation scintigraphy with $\left[{ }^{123}\right.$ I]iododeoxyuridine. Eur J Nucl Med Mol Imaging 2003;30:239-246

62. Kassis AI, Sastry KS, Adelstein SJ. Kinetics of uptake, retention, and radiotoxicity of ${ }^{125} \mathrm{IUdR}$ in mammalian cells: implications of localized energy deposition by Auger processes. Radiat Res 1987;109:78-89

63. Di Croce L, Okret S, Kersten S, Gustafsson JA, Parker M, Wahli W, et al. Steroid and nuclear receptors. Villefranche-sur-Mer, France, May 25-27, 1999. EMBO J 1999;18:6201-6210

64. Beato M, Truss M, Chavez S. Control of transcription by steroid hormones. Ann N Y Acad Sci 1996;784:93-123

65. Yasui LS, Hughes A, DeSombre ER. Cytotoxicity of ${ }^{125} \mathrm{I}-$ oestrogen decay in non-oestrogen receptor-expressing human breast cancer cells, MDA-231 and oestrogen receptor-expressing MCF-7 cells. Int J Radiat Biol 2001;77:955-962

66. Yasui L, Hughes A, DeSombre E. Relative biological effectiveness of accumulated ${ }^{125} \mathrm{IdU}$ and ${ }^{125}$ I-estrogen decays in estrogen receptor-expressing MCF-7 human breast cancer cells. Radiat Res 2001;155:328-334

67. DeSombre ER, Hughes A, Hanson RN, Kearney T. Therapy of estrogen receptor-positive micrometastases in the peritoneal cavity with Auger electron-emitting estrogens-theoretical and practical considerations. Acta Oncol 2000;39:659-666

68. Reilly RM, Kiarash R, Cameron RG, Porlier N, Sandhu J, Hill $\mathrm{RP}$, et al. ${ }^{111}$ In-labeled EGF is selectively radiotoxic to human breast cancer cells overexpressing EGFR. J Nucl Med 2000;41:429-438

69. Chen P, Cameron R, Wang J, Vallis KA, Reilly RM. Antitumor effects and normal tissue toxicity of ${ }^{111}$ In-labeled epidermal growth factor administered to athymic mice bearing epidermal growth factor receptor-positive human breast cancer xenografts. J Nucl Med 2003;44:1469-1478

70. Andersson P, Forssell-Aronsson E, Johanson V, Wangberg B, Nilsson $\mathrm{O}$, Fjalling $\mathrm{M}$, et al. Internalization of indium-111 into human neuroendocrine tumor cells after incubation with indium111-DTPA-D-Phe ${ }^{1}$-octreotide. J Nucl Med 1996;37:2002-2006

71. Ginj M, Hinni K, Tschumi S, Schulz S, Maecke HR. Trifunctional somatostatin-based derivatives designed for targeted radiotherapy using Auger electron emitters. J Nucl Med 2005;46:2097-2103
72. Capello A, Krenning E, Bernard B, Reubi JC, Breeman W, de Jong M. ${ }^{111}$ In-labelled somatostatin analogues in a rat tumour model: somatostatin receptor status and effects of peptide receptor radionuclide therapy. Eur J Nucl Med Mol Imaging 2005;32:1288-1295

73. Kwekkeboom DJ, Mueller-Brand J, Paganelli G, Anthony LB, Pauwels S, Kvols LK, et al. Overview of results of peptide receptor radionuclide therapy with 3 radiolabeled somatostatin analogs. J Nucl Med 2005;46 Suppl 1:62S-66S

74. De Jong M, Valkema R, Jamar F, Kvols LK, Kwekkeboom DJ, Breeman WA, et al. Somatostatin receptor-targeted radionuclide therapy of tumors: preclinical and clinical findings. Semin Nucl Med 2002;32:133-140

75. Krenning EP, Kwekkeboom DJ, Valkema R, Pauwels S, Kvols LK, De Jong M. Peptide receptor radionuclide therapy. Ann N Y Acad Sci 2004;1014:234-245

76. Mester J, DeGoeij K, Sluyser M. Modulation of $\left[5-{ }^{125} \mathrm{I}\right]$ iododeoxyuridine incorporation into tumour and normal tissue DNA by methotrexate and thymidylate synthase inhibitors. Eur J Cancer 1996;32A:1603-1608

77. Kassis AI, Guptill WE, Taube RA, Adelstein SJ. Radiotoxicity of 5-[ $\left.{ }^{125} \mathrm{I}\right]$ iodo-2'-deoxyuridine in mammalian cells following treatment with 5-fluoro-2'-deoxyuridine. J Nucl Biol Med 1991;35:167-173

78. Lawrence TS, Davis MA, McKeever PE, Maybaum J, Stetson PL, Normolle DP, et al. Fluorodeoxyuridine-mediated modulation of iododeoxyuridine incorporation and radiosensitization in human colon cancer cells in vitro and in vivo. Cancer Res 1991;51:3900-3905

79. Dupertuis YM, Vazquez M, Mach JP, de Tribolet N, Pichard C, Slosman DO, et al. Fluorodeoxyuridine improves imaging of human glioblastoma xenografts with radiolabeled iododeoxyuridine. Cancer Res 2001;61:7971-7977

80. Buchegger F, Adamer F, Schaffland AO, Kosinski M, Grannavel C, Dupertuis YM, et al. Highly efficient DNA incorporation of intratumourally injected $\left[{ }^{125} \mathrm{I}\right]$ iododeoxyuridine under thymidine synthesis blocking in human glioblastoma xenografts. Int $\mathrm{J}$ Cancer 2004; 110:145-149

81. Perillo-Adamer F, Bischof Delaloye A, Genton C, Schaffland AO, Dupertuis YM, Buchegger F. Short fluorodeoxyuridine exposure of different human glioblastoma lines induces high level accumulation of S-phase cells that avidly incorporate ${ }^{125} \mathrm{I}$ iododeoxyuridine. Eur J Nucl Med Mol Imaging 2006;33: 613-620

82. Spears CP, Shahinian AH, Moran RG, Heidelberger C, Corbett TH. In vivo kinetics of thymidylate synthetase inhibition of 5 -fluorouracil-sensitive and -resistant murine colon adenocarcinomas. Cancer Res 1982;42:450-456

83. Wilson WL, Bisel HF, Krementz ET, Lien RC, Prohaska JV. Further clinical evaluation of 2'-deoxy-5-fluorouridine (NSC27640). Cancer Chemother Rep 1967;51:85-90

84. Serlin O, Wolkoff JS, Amadeo JM, Keehn RJ. Use of 5fluorodeoxyuridine (FUDR) as an adjuvant to the surgical management of carcinoma of the stomach. Cancer 1969;24: 223-228

85. Pressacco J, Mitrovski B, Erlichman C, Hedley DW. Effects of thymidylate synthase inhibition on thymidine kinase activity and nucleoside transporter expression. Cancer Res 1995;55: $1505-1508$

86. Valdes R, Casado FJ, Pastor-Anglada M. Cell-cycle-dependent regulation of $\mathrm{CNT} 1$, a concentrative nucleoside transporter involved in the uptake of cell-cycle-dependent nucleosidederived anticancer drugs. Biochem Biophys Res Commun 2002;296:575-579 
87. Sedelnikova OA, Panyutin IV, Neumann RD, Bonner WM, Panyutin IG. Assessment of DNA damage produced by ${ }^{125} \mathrm{I}-$ triplex-forming oligonucleotides in cells. Int $\mathrm{J}$ Radiat Biol 2004;80:927-931

88. Panyutin IG, Winters TA, Feinendegen LE, Neumann RD. Development of DNA-based radiopharmaceuticals carrying Auger-electron emitters for anti-gene radiotherapy. Q J Nucl Med 2000;44:256-267

89. Cammilleri S, Sangrajrang S, Perdereau B, Brixy F, Calvo F, Bazin $\mathrm{H}$. Biodistribution of iodine-125 tyramine transforming growth factor alpha antisense oligonucleotide in athymic mice with a human mammary tumour xenograft following intratumoral injection. Eur J Nucl Med 1996;23:448-452

90. He Y, Panyutin IG, Karavanov A, Demidov VV, Neumann RD. Sequence-specific DNA strand cleavage by ${ }^{111}$ In-labeled peptide nucleic acids. Eur J Nucl Med Mol Imaging 2004;31:837-845

91. Lee JF, Stovall GM, Ellington AD. Aptamer therapeutics advance. Curr Opin Chem Biol 2006;10:282-289

92. Lee JH, Canny MD, De EA, Krilleke D, Ng YS, Shima DT, et al. A therapeutic aptamer inhibits angiogenesis by specifically targeting the heparin binding domain of VEGF165. Proc Natl Acad Sci USA 2005;102:18902-18907

93. Farokhzad OC, Cheng J, Teply BA, Sherifi I, Jon S, Kantoff $\mathrm{PW}$, et al. Targeted nanoparticle-aptamer bioconjugates for cancer chemotherapy in vivo. Proc Natl Acad Sci USA 2006;103:6315-6320

94. Hicke BJ, Stephens AW, Gould T, Chang YF, Lynott CK, Heil J, et al. Tumor targeting by an aptamer. J Nucl Med 2006;47: 668-678

95. Pieken WA, Olsen DB, Benseler F, Aurup H, Eckstein F. Kinetic characterization of ribonuclease-resistant 2'-modified hammerhead ribozymes. Science 1991;253:314-317

96. Klussmann S, Nolte A, Bald R, Erdmann VA, Furste JP. Mirrorimage RNA that binds D-adenosine. Nat Biotechnol 1996;14:1112-1115

97. Kim SJ, Kim MY, Lee JH, You JC, Jeong S. Selection and stabilization of the RNA aptamers against the human immunodeficiency virus type-1 nucleocapsid protein. Biochem Biophys Res Commun 2002;291:925-931

98. Welt S, Scott AM, Divgi CR, Kemeny NE, Finn RD, Daghighian F, et al. Phase I/II study of iodine 125-labeled monoclonal antibody A33 in patients with advanced colon cancer. J Clin Oncol 1996;14:1787-1797

99. Govindan SV, Goldenberg DM, Elsamra SE, Griffiths GL, Ong GL, Brechbiel MW, et al. Radionuclides linked to a CD74 antibody as therapeutic agents for B-cell lymphoma: comparison of Auger electron emitters with beta-particle emitters. J Nucl Med 2000;41:2089-2097

100. Michel RB, Rosario AV, Andrews PM, Goldenberg DM, Mattes MJ. Therapy of small subcutaneous B-lymphoma xenografts with antibodies conjugated to radionuclides emitting lowenergy electrons. Clin Cancer Res 2005;11:777-786

101. Michel RB, Andrews PM, Castillo ME, Mattes MJ. In vitro cytotoxicity of carcinoma cells with ${ }^{111}$ In-labeled antibodies to HER-2. Mol Cancer Ther 2005;4:927-937

102. Michel RB, Brechbiel MW, Mattes MJ. A comparison of 4 radionuclides conjugated to antibodies for single-cell kill. J Nucl Med 2003;44:632-640
103. Hosono M, Hosono MN, Kraeber-Bodere F, Devys A, Thedrez $\mathrm{P}$, Fiche $\mathrm{M}$, et al. Biodistribution and dosimetric study in medullary thyroid cancer xenograft using bispecific antibody and iodine-125-labeled bivalent hapten. J Nucl Med 1998;39:1608-1613

104. Sisson JC. Radiopharmaceuticals for nuclear endocrinology at the University of Michigan. Cancer Biother Radiopharm 2000; $15: 305-318$

105. Sisson JC, Shapiro B, Hutchinson RJ, Shulkin BL, Zempel S. Survival of patients with neuroblastoma treated with 125-I MIBG. Am J Clin Oncol 1996;19:144-148

106. Bernhardt P, Forssell-Aronsson E, Jacobsson L, Skarnemark G. Low-energy electron emitters for targeted radiotherapy of small tumours. Acta Oncol 2001;40:602-608

107. Abdel-Nabi H, Ortman JA. Radiobiological effects of ${ }^{131} \mathrm{I}$ and ${ }^{125}$ I on the DNA of the rat thyroid. I. Comparative study with emphasis on the postradiation hypothyroidism occurrence. Radiat Res 1983;93:525-533

108. Dradi C, Riceputi G, Biagioli R, Riva P. Radiotherapy with ${ }^{131} \mathrm{~J}$ and ${ }^{125} \mathrm{~J}$ of Basedow's disease. Indications and results relative to the incidence of post-actinic hypothyroidism [in Italian]. Minerva Med 1979;70:135-141

109. McDougall IR, Greig WR, Gillespie FC. Iodine-125 therapy for thyrotoxicosis: background and evaluation in 148 patients. Strahlentherapie [Sonderb ] 1972;72:243-252

110. McDougall IR, Greig WR, Gray HW, Gillespie FC. Iodine-125 treatment for thyrotoxicosis. Lancet 1970;2:840-842

111. Gillespie FC, Orr JS, Greig WR. Microscopic dose distribution from 125-I in the toxic thyroid gland and its relation to therapy. Br J Radiol 1970;43:40-47

112. Dwyer RM, Bergert ER, O'Connor MK, Gendler SJ, Morris JC. In vivo radioiodide imaging and treatment of breast cancer xenografts after MUC1-driven expression of the sodium iodide symporter. Clin Cancer Res 2005;11:1483-1489

113. Buchsbaum DJ, Chaudhuri TR, Zinn KR. Radiotargeted gene therapy. J Nucl Med 2005;46 Suppl 1:179S-186S

114. De Jong M, Valkema R, Van GA, Van BH, Bex A, Van De Weyer EP, et al. Inhomogeneous localization of radioactivity in the human kidney after injection of $\left[{ }^{111}\right.$ In-DTPA] octreotide. J Nucl Med 2004;45:1168-1171

115. Kassis AI, Tumeh SS, Wen PY, Baranowska-Kortylewicz J, Van den Abbeele AD, Zimmerman RE, et al. Intratumoral administration of 5-[ $\left.{ }^{123} \mathrm{I}\right]$ iodo-2'-deoxyuridine in a patient with a brain tumor. J Nucl Med 1996;37:19S-22S

116. Mariani G, Di Sacco S, Volterrani D, Di Luca L, Buralli S, Di Stefano R, et al. Tumor targeting by intra-arterial infusion of 5$\left[{ }^{123}\right.$ I] iodo-2'- deoxyuridine in patients with liver metastases from colorectal cancer. J Nucl Med 1996;37:22S-25S

117. Mariani G, Di Sacco S, Bonini R, Di Luca L, Buralli S, Bonora $\mathrm{D}$, et al. Biochemical modulation by 5 -fluorouracil and 1folinic acid of tumor uptake of intra-arterial $5-\left[{ }^{123} \mathrm{I}\right]$ iodo- ${ }^{\prime}$ deoxyuridine in patients with liver metastases from colorectal cancer. Acta Oncol 1996;35:941-945

118. Bodei L, Kassis AI, Adelstein SJ, Mariani G. Radionuclide therapy with iodine-125 and other Auger-electron-emitting radionuclides: experimental models and clinical applications. Cancer Biother Radiopharm 2003;18:861-877

119. Xiao J, Horst S, Hinkle G, Cao X, Kocak E, Fang J, et al Pharmacokinetics and clinical evaluation of ${ }^{125}$ I-radiolabeled humanized CC49 monoclonal antibody (HuCC49deltaC(H)2) in recurrent and metastatic colorectal cancer patients. Cancer Biother Radiopharm 2005;20:16-26 